\title{
The intergenerational effects of fetal programming: non-genomic mechanisms for the inheritance of low birth weight and cardiovascular risk
}

\author{
A J Drake and B R Walker \\ Endocrinology Unit, School of Molecular and Clinical Medicine, University of Edinburgh, Molecular Medicine Centre, Western General Hospital, Crewe Road \\ South, Edinburgh EH4 2XU, UK \\ (Requests for offprints should be addressed to A J Drake; Email: mandy.drake@ed.ac.uk
}

\begin{abstract}
Many epidemiological studies in diverse populations have demonstrated a link between low birth weight and subsequent disease. This evidence has given rise to the fetal origins hypothesis, which suggests that exposure of the fetus to an adverse environment in utero leads to permanent programming of tissue function and a risk of cardiovascular disease. An alternative hypothesis is that low birth weight and adult cardiovascular disease are independent features of a genetic predisposition to cardiovascular
\end{abstract}

disease. This review describes evidence that the programming phenomenon may not be limited to the first generation offspring. Results of human and animal studies identify intergenerational programmed effects on both birth weight and cardiovascular disease. This may represent a mechanism for the non-genetic inheritance of a predisposition to low birth weight and adverse cardiovascular risk across a number of generations.

Journal of Endocrinology (2004) 180, 1-16

\section{Introduction: the early life origins of disease}

Many epidemiological studies in distinct populations in the UK and the rest of the world have demonstrated an association between low birth weight and the subsequent development of hypertension, insulin resistance, type 2 diabetes and cardiovascular disease (Barker 1998). This association appears to be independent of classic lifestyle risk factors such as smoking, adult weight, social class, alcohol and lack of exercise, which are additive to the effect (Barker et al. 1993). Importantly, the association holds for the full range of birth weights, including those within the normal range. In addition, a number of studies have suggested that faster postnatal catch-up growth may also be predictive of later risk of cardiovascular disease (Barker et al. 1993, Bavdekar et al. 1999, Eriksson et al. 1999, Forsen et al. 2000, Law et al. 2002). 'Fetal programming' has been proposed as the mechanism underlying this association between low birth weight, childhood growth and subsequent disease. The fetal programming hypothesis proposes that a stimulus or insult acting during critical periods of growth and development may permanently alter tissue structure and function. Indeed, evidence from both human and animal studies (Langley-Evans et al. 1996, Barker 1998, Nyirenda et al. 1998, Doyle et al. 2000) suggests that many diseases of adult life can be induced by manipulating the environmental experience of the fetus.

The relative importance of genetic and environmental factors in this phenomenon remains unknown. Two major environmental hypotheses have been proposed to explain the mechanism by which low birth weight is associated with adult disease: fetal undernutrition (Barker \& Osmond 1986) and overexposure of the fetus to glucocorticoids (Edwards et al. 1993). A third hypothesis suggests that genetic factors may lead to both low birth weight and subsequent risk of cardiovascular disease; indeed, genetic loci have recently been described which may link smallness at birth with adult disease (Dunger et al. 1998, Hattersley et al. 1998).

A somewhat polarised debate has ensued concerning whether the mechanisms of the low birth weight/adult disease associations are programmed/environmental or genetic. As with most nature vs nurture arguments, the answer is probably a mixture of the two. To add to this complexity, however, there is evidence that what appears to be inherited, and implicitly 'genetic', may in fact represent a perpetuation of a programming influence through several generations. There is a well-recognised 'intergenerational cycle of growth failure' in the developing world - young girls who grow poorly become stunted 
women and are more likely to give birth to low birth weight babies. If these infants are girls, they are likely to continue the cycle by being stunted in adulthood and so on (Ramakrishnan et al. 1999). Could this apparent intergenerational effect on fetal growth also be important in the developed world? Moreover, could such an effect contribute to adult cardiovascular disease in Westernised societies?

\section{Intergenerational influences}

In 1986, Emanuel defined intergenerational influences as 'those factors, conditions, exposures and environments experienced by one generation that relate to the health, growth and development of the next generation' (Emanuel 1986). Epidemiological studies have suggested that there may be intergenerational effects on birth weight (Ounsted \& Ounsted 1968, Johnstone \& Inglis 1974, Klebanoff et al. 1984, Emanuel et al. 1992, Hennessy \& Alberman 1998, Collins et al. 2002). If low birth weight is associated with increased cardiovascular risk, this could lead to the 'inheritance' of a predisposition to low birth weight and adverse cardiovascular risk across a number of generations (Fig. 1).

Potential explanations for intergenerational effects include: (i) that genetic attributes may manifest themselves similarly in mother and offspring; (ii) that adverse extrinsic environmental conditions may persist across generations; and (iii) that adverse in utero experiences may permanently affect maternal growth and development, altering her metabolism in such a way as to provide an adverse environment for her fetus. This last hypothesis suggests a mechanism by which programming effects could be self-perpetuating through several generations.

This review will examine the evidence for intergenerational effects on birth weight and adult disease, and whether non-genomic mechanisms may operate to produce programming effects across a number of generations.

\section{Intergenerational effects on birth weight}

Studies in a number of different populations have demonstrated that offspring birth weight is related to maternal birth weight (Ounsted \& Ounsted 1968, Johnstone \& Inglis 1974, Klebanoff et al. 1984, 1989, 1997, Carr-Hill et al. 1987, Emanuel et al. 1992, 1999, Collins et al. 2002), a relationship which appears to depend upon reduced intrauterine growth rather than reduced duration of gestation (Klebanoff et al. 1984, 1997). In 1968, Ounsted published data from a cohort of growth-retarded and growth-accelerated infants taken from the British Perinatal Mortality survey of 1958 and suggested a matrilineal pattern of birth weight inheritance (Ounsted \& Ounsted 1968). However, the study was too small to exclude a major contribution of the father to offspring birth weight. Subsequently, extensive study of the 1958 birth cohort from the British National Child Development Study showed a direct association between parental and offspring birth weight (Alberman et al. 1992, Emanuel et al. 1992, Hennessy \& Alberman 1998), and assessment of grandparental data in these and other studies has also provided evidence for a matrilineal multigenerational effect on birth weight (Emanuel et al. 1992, Klebanoff et al. 1997). Although there is a significant relationship between paternal and offspring birth weight (Emanuel et al. 1992, Klebanoff et al. 1998, Magnus et al. 2001), this association is not as strong as that for maternal birth weight (Alberman et al. 1992, Emanuel et al. 1992, Coutinho et al. 1997, Klebanoff et al. 1998).

Intergenerational effects on birth weight are also seen in the developing world. Prospective studies in rural Guatemala found a clear relationship between maternal and offspring birth weight, with an effect nearly twice that seen in developed countries (Ramakrishnan et al. 1999).

In addition, secular trends in birth weight may be mediated by intergenerational factors. Studies in the US have identified differing intergenerational birth weight effects among African-American and white populations in Illinois depending on place of birth (Collins et al. 2002), suggesting that environmental factors may be influencing the secular trends in birth weight in populations with the same racial background.

\section{Intergenerational effects on cardiovascular risk factors}

The link between low birth weight and adult cardiovascular risk could be confounded if both low birth weight and cardiovascular risk were inherited together. If this were the case, then we might expect both parents to have an equal influence on the inheritance of birth weight and later cardiovascular disease. A number of recent studies have demonstrated relationships between parental risk of cardiovascular disease and offspring birth weight (Davey Smith et al. 1997, 2000a,b, Smith et al. 2001, Lawlor et al. $2003 a, b$ ). Although not a universal finding (Kinra et al. 2003), there is evidence in these studies that parental influence is not equal such that the association of maternal cardiovascular risk with offspring birth weight and cardiovascular risk is stronger than that of the father (Davey Smith et al. 1997, Kuznetsova et al. 2003).

Considering individual cardiovascular risk factors, there is a well-documented relationship between parental and offspring blood pressure (Watt et al. 1991, Walker et al. 1998) (Fig. 2). There is also evidence that the inheritance of low birth weight and hypertension may be linked. Mothers with higher blood pressure in later life have been shown to deliver smaller babies, a relationship that confounds that which is found between low birth weight and 


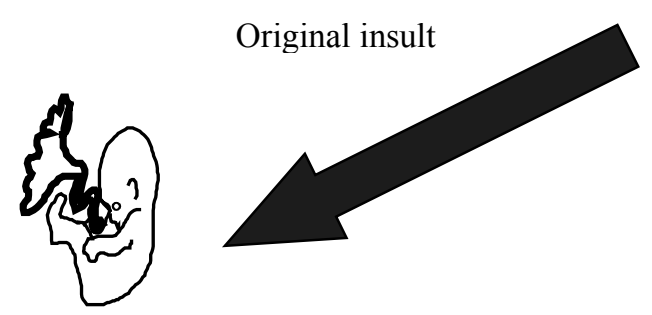

Infant

Low birth weight

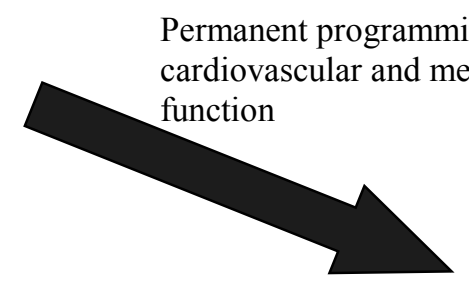

Perpetuation of insult to next generation e.g.

$\uparrow$ maternal cortisol

$\uparrow$ maternal insulin

$\uparrow$ maternal BP
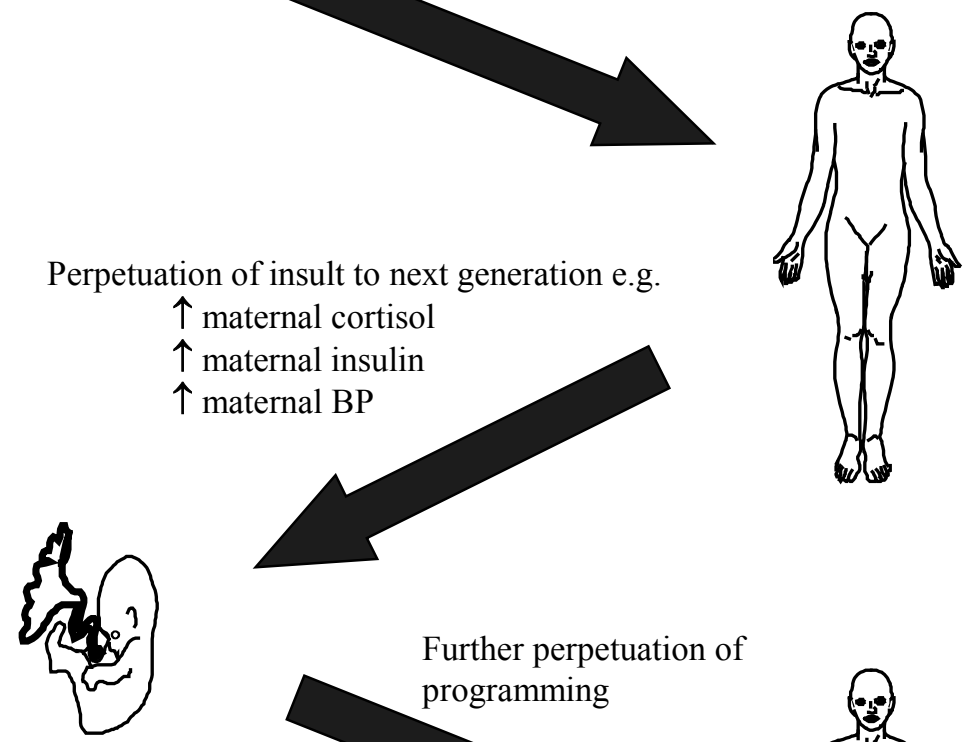

\section{Adult}

Increased cardiovascular risk

High blood pressure

HPA axis activation

Insulin resistance

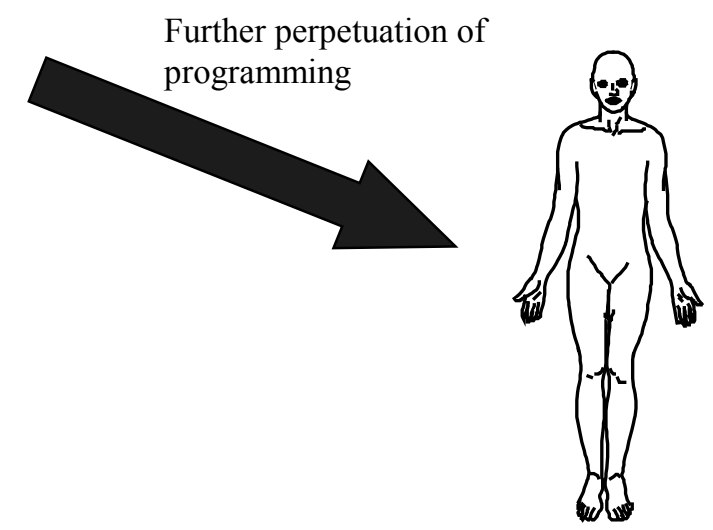

Figure 1 Proposed model for intergenerational programming of birth weight and cardiovascular risk. Exposure of the mother to an adverse environment results in a developmental signal to the F1 offspring, resulting in physiological changes or 'programming'. These changes, with or without continuing environmental stress, lead to a developmental signal for the F2 generation, and thus a cycle of intergenerational programming.

adult hypertension (Walker et al. 1998, Lawlor et al. 2002) (Fig. 2). Women who were small for gestational age are at increased risk of developing hypertension during pregnancy (Klebanoff et al. 1999), and hypertension during pregnancy predicts the delivery of low birth weight babies (Misra 1996, Ferrer et al. 2000, Brown et al. 2001, Buchbinder et al. 2002). Additionally, there is a continu- ous inverse association between fetal growth and maternal blood pressure across the range seen in normal pregnancy; higher maternal diastolic blood pressure during later pregnancy is predictive of lower offspring birth weight (Churchill et al. 1997). However, although paternal blood pressure is associated with offspring blood pressure, it does not reliably predict offspring birth weight 

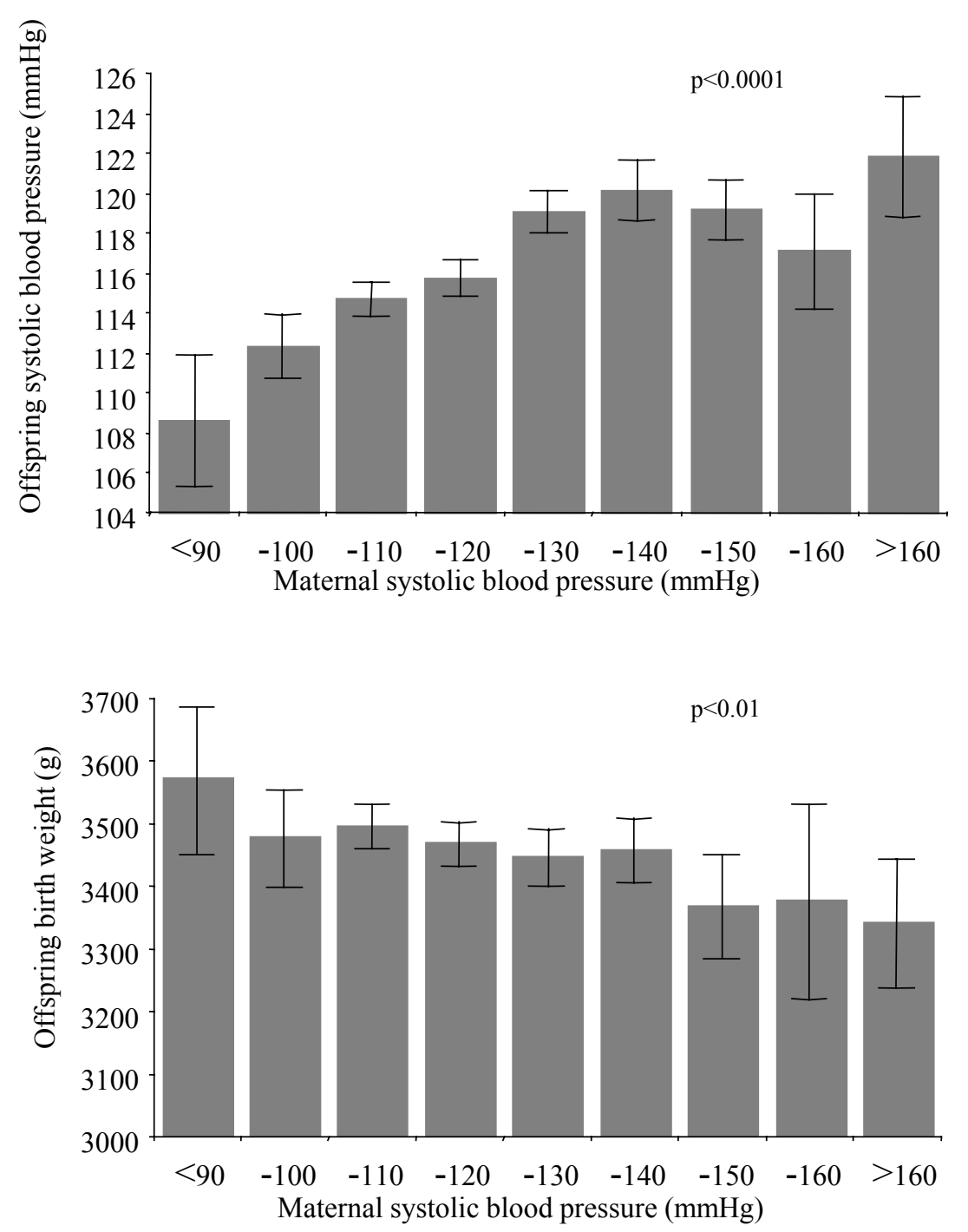

Figure 2 Offspring blood pressure is related to maternal blood pressure. Higher maternal blood pressure is associated with higher offspring blood pressure and lower birth weight in a study of 452 young adults. These relationships confound that which is found between low birth weight and adult hypertension in the offspring. (Adapted from Walker et al. 1998.)

(Walker et al. 1998). Furthermore, lower maternal but not paternal birth weight is related to higher offspring blood pressure, an association which is largely independent of the relationship between maternal and offspring birth weight (Barker et al. 2000).

There have been many studies of the association of parental diabetes with offspring diabetes risk (Alcolado \& Alcolado 1991, Thomas et al. 1994, Klein et al. 1996, Viswanathan et al. 1996, Karter et al. 1999, Dabelea et al. 2000a, Lindsay et al. 2000, Meigs et al. 2000, Yajnik et al. 2001). Studies of women in the US Nurses study, and those from Pima Native American populations have dem- onstrated that the offspring of mothers with diabetes during pregnancy were at increased risk of developing type 2 diabetes (Pettitt et al. 1993, Dabelea et al. 2000a, Lindsay et al. 2000). A further study involving 15000 families showed a modest excess in maternal over paternal transmission of type 2 diabetes in a multiethnic population in the US, although the relationships varied between racial groups and appeared stronger in the female offspring (Karter et al. 1999). Excess maternal transmission of type 2 diabetes has been confirmed in some (Alcolado \& Alcolado 1991, Lin et al. 1994, Thomas et al. 1994, Groop et al. 1996, Klein et al. 1996, Riley et al. 1997, 
Bjornholt et al. 2000), but not all other populations (Mitchell et al. 1995, McCarthy et al. 1996, Viswanathan et al. 1996, Meigs et al. 2000). However, the association between maternal diabetes, offspring birth weight and subsequent diabetes is complex because gestational diabetes predisposes to macrosomic infants with higher birth weight (Silverman et al. 1991). Women of low birth weight are at increased risk of developing gestational diabetes and type 2 diabetes (Williams et al. 1999, Egeland et al. 2000, Forsen et al. 2000, Innes et al. 2002, Seghieri et al. 2002) and hence deliver larger babies (Seghieri et al. 2002). 'Macrosomic' offspring are themselves at risk of developing obesity (Pettitt et al. 1993, Gillman et al. 2003), gestational diabetes (Innes et al. 2002) and type 2 diabetes later in life (Pettitt et al. 1993, Lindsay et al. 2000, Catalano et al. 2003). Thus, some studies have confirmed a U-shaped relationship between a woman's risk for developing gestational diabetes and her own birth weight (Egeland et al. 2000, Innes et al. 2002). This may obscure inferences about intergenerational relationships between birth weight and risk of type 2 diabetes. The complexity of dissecting programmed from genetic phenomena is also most clearly illustrated in studies of diabetes risk, for example in the Pima Indian community in which there is a very high prevalence of maternal diabetes. In this population, low birth weight is associated with the subsequent development of type 2 diabetes, but only if paternal diabetes is also present (Lindsay et al. 2000). Maternal diabetes alone is still associated with an increased risk of type 2 diabetes in the offspring, but in individuals with higher rather than lower birth weight (Pettitt et al. 1993, Dabelea et al. 2000a, Lindsay et al. 2000). This suggests that it is paternal diabetes which is associated with lower offspring birth weight, and this has been confirmed in some (Yajnik et al. 2001, Hypponen et al. 2003), but not all (Rich-Edwards et al. 1999), further studies elsewhere. It has been inferred that the association of low birth weight and diabetes reflects the influence of genetic factors (Dunger et al. 1998, Hattersley \& Tooke 1999). Indeed, it has recently been shown that in the Pima population, birth weight is linked to a locus on chromosome 11, with evidence for an imprinted, paternally expressed gene (Lindsay et al. 2002a). There is, however, little evidence of parent-specific linkage of diabetes at this locus, and indeed a number of genes associated with insulin resistance are not associated with birth weight in the Pima population (Lindsay et al. 2002b). Moreover, extrapolating findings in a population with very high genetic predisposition to diabetes to other populations may not be valid, since the relative importance of non-genetic mechanisms may be greater elsewhere.

Thus, although there are maternal and paternal effects on offspring birth weight and susceptibility to type 2 diabetes and cardiovascular disease which may be genetic and/or environmental, there is evidence for a specific influence of maternal rather than paternal characteristics which may represent a process of intergenerational programming.

\section{Intergenerational effects in animal models of programming}

Observational studies have been of fundamental value in generating the hypotheses of the early life origins of disease. However, to dissect and validate mechanisms has required extensive animal studies (Benediktsson et al. 1993, Seckl 1997, 1998, Hoet \& Hanson 1999, Challis et al. 2001, Meaney 2001). Although most attention has been given to the 'first generation' of offspring exposed to a manipulation when in utero, there is a substantial body of evidence from animal studies that programmed phenomena can be perpetuated in later generations. Animal models of prenatal programming by nutrition or exercise, and postnatal programming by nutrition or handling have shown effects on birth weight (Stewart et al. 1975, Pinto \& Shetty 1995), glucose tolerance (Martin et al. 2000, Patel et al. 2001) and the hypothalamic-pituitary axis (Francis et al. 1999) in subsequent generations.

\section{Programming of birth weight}

Intergenerational effects of dietary manipulations on birth weight have been demonstrated in black-and-white hooded rats (Stewart et al. 1975) (Fig. 3). Colonies of rats were maintained for 12 generations on a control diet or a diet marginally deficient in protein. Birth weight was reduced in the first generation of malnourished animals and this effect of poor maternal diet on birth weight appeared to be amplified in subsequent generations. Midway through this intergenerational experiment a more unpalatable diet was introduced by chance. Following this, further reduction in birth weight was seen in the malnourished colony and in addition, there was a slight reduction in birth weight in the control colony. After the reintroduction of more palatable chow, birth weight in control animals increased, but did not return to baseline for approximately three generations despite the resumption of normal nutrition. The study demonstrates that continued poor maternal nutrition produces amplified effects on birth weight through a number of generations. However, the accidental introduction of less-palatable food, which resulted in a period of self-imposed calorie restriction in the 'control' animals, also provides evidence that poor nutrition in one generation can produce effects on birth weight in subsequent generations. This effect was confirmed in further experiments when a number of animals from the malnourished colony weaned onto the control diet did not achieve an adult size equivalent to that of the control animals for three further generations (Stewart et al. 1980).

Intergenerational effects on birth weight in rats have also been shown following maternal exercise during 


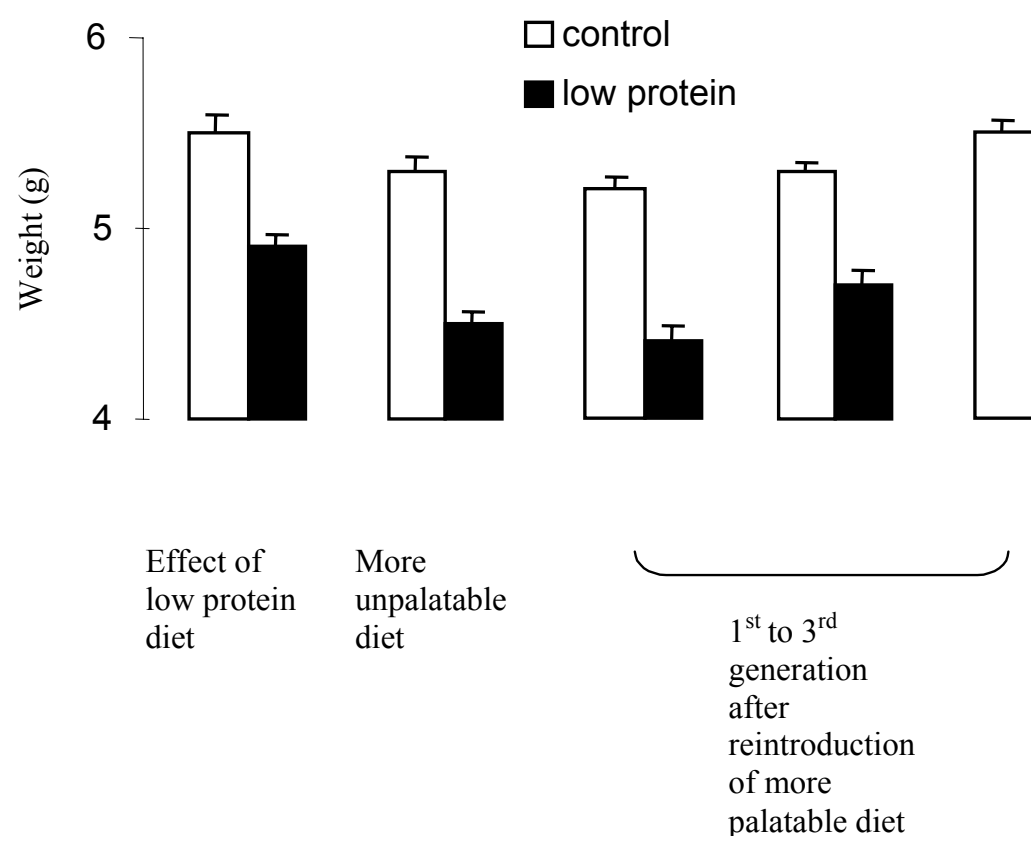

Figure 3 Intergenerational effects of protein deficiency on birth weight in rats. Rats from the same colony were maintained on a control diet or a diet marginally low in protein. F1 offspring of rats on the lower protein diet showed an immediate reduction in birth weight and thereafter showed a progressive reduction in birth weight over a number of generations. Additionally, for litters six and seven, a more unpalatable diet was accidentally introduced to both groups, leading to a reduction in birth weight in rats on the control diet, and a further reduction in birth weight in the malnourished group. Birth weights remained reduced in the control group for two further generations after a more palatable diet was re-introduced. (Adapted from Stewart et al. 1975.) Data are mean \pm S.E.M.

pregnancy and lactation (Pinto \& Shetty 1995). Exercise during pregnancy (swimming) resulted in low birth weight first generation (F1) pups. The second generation (F2) offspring of growth-retarded F1 animals that were sedentary during pregnancy were also found to be growth retarded, suggesting an adverse intergenerational influence of maternal exercise stress on fetal growth in these animals.

\section{Programming of metabolic parameters and blood pressure}

Recent studies have demonstrated other intergenerational effects in animal models. Fetal undernutrition can produce effects on glucose homeostasis in an F2 generation of rats (Martin et al. 2000). Intergenerational effects on birth weight and the endocrine pancreas have also been reported following the use of a low protein, isocaloric diet (Hoet \& Hanson 1999).

Intergenerational effects on blood pressure in rabbits have recently been demonstrated in an experiment in which females with surgically induced hypertension were mated with normotensive males (Denton et al. 2003). The female offspring of hypertensive rabbits had increased blood pressure as adults when compared with the offspring of sham-operated females, although blood pressure in male offspring was unaffected (Denton et al. 2003).

\section{Postnatal programming}

Postnatal programming may also have intergenerational effects. Overfeeding in the neonatal period has been shown to produce second generation effects on glucose homeostasis (Laychock et al. 1995, Vadlamudi et al. 1995, Patel et al. 2001, Srinivasan et al. 2003).

Additionally, postnatal environmental manipulations programming the hypothalamic-pituitary-adrenal (HPA) axis stress response may produce intergenerational effects. A number of studies suggest that differences in behavioural and neuroendocrine responses to stress may be transmitted from one generation to another by non-genomic mechanisms (Meaney 2001). In rodents, naturally occurring variations in maternal behaviour are associated with different HPA stress responsiveness in offspring (Liu et al. 1997). Cross-fostering studies have demonstrated that such differences in maternal behaviour, and therefore differences in offspring stress reactivity, may be transmitted across generations by non-genomic mechanisms 
(Francis et al. 1999). Additionally, postnatal handling of rat pups is associated with programming of the HPA axis; handled offspring show reduced HPA responses to stress and increased maternal care behaviour (Francis et al. 1999). Again, these individual differences in maternal behaviour and HPA responses can be transmitted from one generation to another (Francis et al. 1999).

\section{Mechanisms of intergenerational inheritance}

From the above, it is clear that intergenerational programming can occur, even in the absence of a continuing environmental stimulus. The evidence in animals is more clearcut than the evidence in humans, in part because of experimental design allowing controlled experiments and probably also because of the genetic homogeneity of animal colonies, in which confounding effects of genetic influences play a much smaller role. It appears that permanent 'programming' of maternal physiology may lead to the persistence of programming effects across a number of generations. Such effects might be advantageous, as in the secular changes of increasing birth weight across generations which have been documented in some populations (Chike-Obi et al. 1996, Skjaerven et al. 2000, Kramer et al. 2002), or deleterious, as in the perpetuation of low birth weight and higher blood pressure (Barker et al. 1989, Walker et al. 1998). Why might the environmental experience of one generation affect the offspring of subsequent generations, and how might such intergenerational effects be mediated? A model is presented in Fig. 1.

\section{Maternal growth}

Exposure of the fetus to an adverse environment in utero may lead to permanent alterations in physiology in adulthood. Such physiological changes may result in an adverse intrauterine environment for the offspring of the individual, leading to physiological changes in the next generation and so on. There is evidence that poor maternal intrauterine growth is associated with reduced weight gain during pregnancy (Hackman et al. 1983), suggesting that pregnancy may be affected by physiological changes consequent on poor maternal growth. The importance of maternal size in determining the intrauterine growth of offspring has been demonstrated with cross-breeding experiments in Shetland ponies and Shire horses (Walton \& Hammond 1938). The offspring were smaller when the Shetland pony rather than the Shire horse was the mother, suggesting that maternal size has an important influence on the size of the offspring. Indeed, short women have small babies (Cawley et al. 1954), and British mothers whose stature equalled or exceeded that predicted from midparental height had bigger babies than mothers of smaller stature (Emanuel 1997). Animal studies have shown that organ size is affected by intrauterine malnutrition (Stewart et al. 1975), and girls born small for gestational age and remaining small have reduced uterine and ovarian size (Ibanez et al. 2000). Reduced uterine size in growthretarded females who do not demonstrate catch-up growth and who fail to attain the final height predicted from their genetic potential may therefore have intergenerational effects on birth weight.

However, the growth-retarded babies most likely to develop adult cardiovascular risk factors are those who catch up most in terms of growth in childhood. These mothers will not, therefore, be small at the time of conceiving the next generation, suggesting that maternal size is unlikely to account for intergenerational programming of cardiovascular risk.

\section{Socio-economic factors}

Socio-economic factors may have a role in intergenerational effects. Lifelong minority status and disadvantage amongst black women in the US may have played a key part in perpetuating poor intrauterine growth across a number of generations (Collins et al. 2002). In two Swedish cohorts born in the 1920s and in 1985, household social class was shown to have a clear influence on birth weight (Vagero \& Leon 1994). However, social class is (at least conventionally) as much influenced by paternal as by maternal circumstances, so is unlikely to account for matrilineal inheritance.

Conversely, improvements in the environment and in maternal health could also have intergenerational effects on offspring growth. Secular trends in some populations show increases in mean birth weight of 40-100 g over decades (Chike-Obi et al. 1996, Skjaerven et al. 2000, Collins et al. 2002). Such a rapid increase in the mean population birth weight provides evidence of the importance of environmental factors in the expression of genetic potential.

\section{Nutrition}

One of the major factors proposed to explain fetal programming is maternal undernutrition, and studies in humans and animals suggest that this may have intergenerational consequences. There is no doubt that in developing countries, maternal diet can affect birth weight, and may be extremely important in mediating intergenerational effects on birth weight and adult disease. Such effects may also be mediated, or indeed amplified, by adverse environmental conditions persisting across a number of generations. In animal models, second generation effects have been noted following impaired nutrition in utero, and exposure during specific time-windows of development may be important (Stewart et al. 1975, 1980, Laychock et al. 1995, Hoet \& Hanson 1999, Martin et al. 2000). However, these occur even when nutrition is 
normal in the F2 generation, so that perpetuation of the insult may not be required to express the effect in later generations.

Initial results from the Dutch famine studies suggested that there may be second generation effects following a specific environmental insult in a previously healthy population (Lumey 1992). The effects of malnutrition have been reported widely following the Dutch famine of 1944-1945 when the Western Netherlands was affected by acute famine, a period known as the 'Hunger Winter'. The famine ceased immediately with liberation in May 1945, after which food supplies became abundant. Initial studies suggested that mothers with first and second trimester exposure to famine later delivered offspring (F2) of lower birth weight than those not exposed to famine (Lumey 1992). However, this study was potentially flawed in a number of ways, including that birth weights in famine-exposed mothers were not directly ascertained but were extrapolated from another group. A subsequent study found no significant effect of maternal famine exposure on their F2 offspring birth weight (Stein \& Lumey 2000).

In developed countries, dietary deficiency is rarely thought to be a significant cause of impaired fetal growth (Godfrey \& Robinson 1998, Mathews et al. 1999, Robinson et al. 2000). However, recent studies suggest that women with eating disorders are more likely to give birth to low birth weight infants (Conti et al. 1998). Although dietary supplementation has been shown to increase birth weight in a study of women in the Gambia (Ceesay et al. 1997), most studies have only demonstrated a small effect (Kramer 2002). One small study in Guatemala has demonstrated that nutritional supplementation of girls during early childhood may have a positive effect on the birth weight and height of their offspring (Stein et al. 2003). Birth weight is influenced by maternal body composition as well as nutrition during pregnancy (Barker 1998) and it is likely that fetal development may be influenced by micronutrient as well as macronutrient deficiency (Boucher 1998). However, so far, single micronutrient supplementation trials have generally not shown a significant effect on birth weight (Fall et al. 2003, Merialdi et al. 2003).

Thus, the role of impaired nutrition in intergenerational effects on birth weight and cardiovascular risk remains uncertain, but may be particularly important in maintaining the cycle of intergenerational programming in developing countries.

\section{Glucocorticoids}

Another major hypothesis advanced to explain fetal programming effects is that of fetal glucocorticoid overexposure (Benediktsson et al. 1993, Edwards et al. 1996). Glucocorticoids are associated with long-term organisational effects, and glucocorticoid treatment during pregnancy has been shown to reduce birth weight in animals
(Reinisch et al. 1978, Ikegami et al. 1997, Nyirenda et al. 1998, Newnham et al. 1999, Newnham 2001). In rats, antenatal dexamethasone treatment leads to hypertension (Benediktsson et al. 1993), elevated hepatic gluconeogenic enzymes and impaired glucose tolerance in the adult offspring (Nyirenda et al. 1998, Cleasby et al. 2003). In fetal sheep its use has been associated with reduced birth weight, changes in blood pressure, altered insulin responses to a glucose challenge and delayed brain myelination (Dunlop et al. 1997, Newnham 2001).

Glucocorticoids are widely used in the management of women at risk of preterm delivery to enhance fetal lung maturation, and in the antenatal management of fetuses at risk of congenital adrenal hyperplasia. Human studies have confirmed that antenatal glucocorticoid administration is associated with a reduction in birth weight (French et al. 1999, Bloom et al. 2001), although normal birth weight has been reported in infants at risk of congenital adrenal hyperplasia who received low-dose dexamethasone in utero from the first trimester (Forest et al. 1993, Mercado et al. 1995). Antenatal glucocorticoid administration has also been linked with higher blood pressure in adolescence (Doyle et al. 2000).

Fetal undernutrition and fetal glucocorticoid overexposure may be linked by a common mechanism (Phillips et al. 1994, Langley-Evans et al. 1996). The enzyme $11 \beta$-hydroxysteroid dehydrogenase type 2 (11ß HSD 2) converts active glucocorticoids to inactive products, and is present in the placenta; the enzyme may act as a barrier to protect the fetus from maternal glucocorticoids (Benediktsson et al. 1993). Reduced placental $11 \beta$ HSD 2 gene expression has been reported in human pregnancies complicated by intrauterine growth retardation (Benediktsson et al. 1995, McTernan et al. 2001), and rodent studies have demonstrated that dietary restriction during pregnancy reduces placental $11 \beta$ HSD 2 expression (Langley-Evans et al. 1996) and disturbs the neonatal HPA axis (Lesage et al. 2001). Thus, maternal malnutrition potentially exerts programming effects by inducing fetal overexposure to the effects of maternal glucocorticoids.

Furthermore, in animal models (Nyirenda et al. 1998, Welberg et al. 2000) and in humans (Phillips et al. 1998, Levitt et al. 2000, Reynolds et al. 2001), plasma glucocorticoids are elevated in adults born with lower birth weight. As prenatal glucocorticoid exposure lowers birth weight and is associated with later hypertension in humans and animal models (Nyirenda et al. 1998, Doyle et al. 2000, Newnham 2001), elevated glucocorticoid levels might potentially mediate both lower birth weight and hypertension through a number of generations.

\section{Blood pressure}

Other possible mechanisms underlying intergenerational effects include haemodynamic changes, which may be self-perpetuating in subsequent generations. One such 
mediator of this effect may be blood pressure; lower maternal birth weight is associated with an increased risk of hypertension during pregnancy (Klebanoff et al. 1999) and higher maternal blood pressure during pregnancy is associated with lower offspring birth weight (Churchill et al. 1997, Ferrer et al. 2000, Brown et al. 2001, Buchbinder et al. 2002), and with higher offspring blood pressure (Walker et al. 1998). In addition, maternal birth weight is related to offspring blood pressure (Barker et al. 2000). Although one study found that the association between maternal birth weight and offspring blood pressure was independent of maternal blood pressure later in life (Barker et al. 2000), this apparently inherited effect may represent intergenerational influences on fetal programming, with low birth weight and subsequent higher blood pressure influencing fetal growth in such a way as to perpetuate this phenomenon. Indeed this is supported by a recent study demonstrating higher blood pressure in the female offspring of rabbits with secondary hypertension (Denton et al. 2003).

\section{Sex-specific effects}

A number of sex-specific effects have been described in animal models of fetal programming (Hales et al. 1996, Dean \& Matthews 1999, Kind et al. 1999, Lingas et al. 1999, Smith \& Waddell 2000, Dean et al. 2001, Lingas \& Matthews 2001, Liu et al. 2001, Owen \& Matthews 2003), with females appearing to be more sensitive to some programming effects (Smith \& Waddell 2000, Denton et al. 2003). Human studies have revealed some sex differences in the long-term disease risk associated with low birth weight (Forsen et al. 2000, Walker et al. 2002), or exposure to famine prenatally (Ravelli et al. 1999). Such sex-specific effects may represent the differential sensitivity of males and females to programming phenomenon and stronger programming in females may further amplify the matrilineal pattern of intergenerational inheritance.

\section{Epigenetic mechanisms}

Molecular mediators of programming of physiology by events in early life remain obscure, and any role in intergenerational programming is therefore speculative. Modification of the genome over and above alterations in nucleotide sequence, or 'epigenetic' modification, is thought to be important in maintaining different patterns of gene expression in different cell groups, in the establishment of the choice of parental allele expressed in germ cells and beyond (parental imprinting), and in the erasure of epimutations (Rakyan et al. 2001). Epigenetic control of gene expression is likely to be mediated by alterations in DNA methylation and/or modifications of chromatin packaging, possibly via changes in histone acetylation. Both mechanisms may influence transcriptional activity and thus gene expression, mainly by the transcriptional silencing of the modified allele (Rakyan et al. 2001). Such modifications influence gene expression, are established early in development and maintained throughout life and may affect the phenotype without changing the DNA sequence, making them prime candidates to explain programming. Epigenetic modification is not restricted to parentally imprinted genes, and the variable expression of some identical alleles within a population may therefore be due to epigenetic modulation rather than genetic differences or adult environmental influences (Rakyan et al. 2001).

A number of genes important in modulating fetal growth, particularly those involved in the control of the expression of insulin-like growth factor (IGF)-II, are imprinted; indeed, loss of imprinting of the IGF-II gene in humans leads to Beckwith-Wiedemann syndrome, associated with fetal overgrowth. In addition, IGF-II and a number of related genes are imprinted in the placenta (Young 2001) and it has been proposed that the IGF-II gene and perhaps others may control the placental supply of nutrients to the fetus, and thus affect fetal growth (Constancia et al. 2002, Reik et al. 2003). In mice, manipulations leading to alterations in the expression of imprinted genes in fetal tissues and in the placenta have been shown to be associated with alterations in fetal growth (Reik et al. 2003). Imprinting of genes has been proposed as the mechanism behind the association of lower offspring birth weight with paternal diabetes in the Pima Indian population (Lindsay et al. 2000, 2002a), and in the parental differences seen in the transmission of class III alleles of the variable number tandem repeat minisatellite $5^{\prime}$ to the insulin gene, variations in which have been associated with type 2 diabetes (Huxtable et al. 2000).

The epigenetic silencing of one allele of a gene according to the parent of origin, or parental imprinting, is usually thought to be erased through meiosis and reestablished in the offspring. However, recent evidence suggests that epigenetic modifications at some other alleles may not be completely erased during gametogenesis and embryogenesis, potentially resulting in the intergenerational inheritance of the epigenetic state (Roemer et al. 1997, Morgan et al. 1999). Very recently it has been shown in mice that the variable expressivity of an allele affecting tail development corresponds with differential methylation, which shows transgenerational epigenetic inheritance after both paternal and maternal transmission, displays parent of origin effects (the penetrance of the abnormal tail phenotype is greater after paternal transmission) and is influenced by the strain background (Rakyan et al. 2003).

Imprinting of genes can be modified by environmental factors (Reik et al. 2003) and imprinted genes may be more vulnerable to methylation changes than the rest of the genome (Young 2001). Embryo culture experiments have shown that environmental influences can permanently affect gene expression and have profound effects on 
growth (Reik et al. 1993, Dean et al. 1998, Khosla et al. 2001, Young et al. 2001). Manipulations of the culture medium of the pre-implantation embryo can result in fetal overgrowth in sheep, in association with reduced methylation and a consequent reduction in expression of the IGF-II receptor gene (Young et al. 2001), and reduction in fetal weight associated with reduced expression of IGF-II and H19 in mice (Khosla et al. 2001), perhaps representing epigenetic mechanisms affecting fetal growth. Intriguingly, many growth factors, including IGF-II, are regulated by glucocorticoids in fetal and adult tissues in vivo and in vitro (Luo et al. 1990, Li et al. 1993, 2002, Miell et al. 1994, Mouhieddine et al. 1996, Forhead et al. 1998). Offspring IGFs are also affected by maternal nutrition in rats (Woodall et al. 1996, Petrik et al. 1999) and in humans (Barker et al. 1993). Very recently, altered maternal diet during pregnancy has been shown to increase methylation of the agouti gene and alter the phenotype of Agouti Yellow mouse pups. These mice are obese and yellow, due to a mutation in the agouti gene; however, pups born to mothers supplemented with vitamins during pregnancy were found to be thin and brown, and had altered methylation at the agouti locus (Waterland \& Jirtle 2003).

Thus, environmental factors including nutrition and glucocorticoid exposure in the fetus could potentially influence the expression of genes, affecting fetal growth and later disease risk. If such epigenetic modifications were not erased during gametogenesis and embryogenesis, this could lead to the transgenerational inheritance of 'programmed effects' (Reik et al. 2003). Indeed, nutritionmediated epigenetic effects have been proposed as a mechanism to explain the apparent transgenerational inheritance through the male line of cardiovascular disease and diabetes risk described in Swedish men (Kaati et al. 2002, Pembrey 2002). Furthermore, evidence is emerging for selective methylation/demethylation of specific promoters of the glucocorticoid receptor gene in association with variations in maternal care (Weaver et al. 2002) which also appear to be inherited.

\section{Intergenerational programming and disease in transitional populations}

The thrifty phenotype hypothesis includes the concept that 'the poorly nourished mother essentially gives the fetus a forecast of the nutritional environment into which it will be born' (Hales \& Barker 2001). Intergenerational phenomena would favour infant survival, providing for transfer of information on the extra-uterine environment from mother to fetus. Physiological adaptations prepare the fetus for the same extra-uterine conditions, optimising survival at least until after reproduction, under conditions of stress or deprivation. Such non-genomic influences on fetal growth and development acting across a number of generations would help to ensure continued population survival, and whilst manifest in both sexes, would be most important in the female line, to optimise reproductive capacity.

However, these intergenerational effects of fetal programming would only be advantageous to population survival when environmental conditions remain consistent over several generations. Any rapid change in the environment puts the 'programmed' offspring at risk of hypertension and glucose intolerance, and the risk of these conditions is amplified by obesity. This is clearly seen in developing countries where peoples leading 'traditional' lifestyles have a low prevalence of type 2 diabetes (King \& Rewers 1993). The prevalence of diabetes, hypertension and cardiovascular disease in such populations increases rapidly with urbanisation or migration to other countries, associated with changes in diet, exercise and the resultant increase in obesity (Cruickshank et al. 2001, Fall 2001). In addition, migrant populations are more likely to live in poor social conditions, with reduced access to health care (Greenhalgh 1997).

Thus, among populations in developing countries who continue to live traditional lifestyles, 'programming' of the fetus would continue to be advantageous under conditions of environmental deprivation, and a cycle of intergenerational programming may result (Fig. 1). Rapid urbanisation of such populations, however, would lead to an increase in the prevalence of type 2 diabetes and other cardiovascular risk factors. Indeed, such effects have been noted in many ethnic groups, and have been particularly studied in the Pima Indian population of Arizona and the Polynesian and Micronesian populations, who have a very high prevalence of obesity and type 2 diabetes. In addition, gestational diabetes is more common among those who have moved from non-industrialised to industrialised societies (Fall 2001). In females, this increased risk of type 2 diabetes or gestational diabetes is likely to result in macrosomic offspring, themselves at increased risk of glucose intolerance in later life.

The thrifty phenotype hypothesis also predicts that improved environmental conditions would eventually lead to a decline in the prevalence of conditions such as type 2 diabetes and other cardiovascular risk factors, as better maternal health and nutrition result in improved fetal growth. Maternal physiology may respond to improvements in the environment in a manner that regulates fetal development, leading to improved fetal growth, and lowering the risk of the metabolic complications associated with low birth weight. Indeed this appears to be so in a number of developed countries, in which the transition from 'traditional lifestyles' to modern society has been very slow. The secular changes of increasing birth weight noted over a number of generations in some populations (Chike-Obi et al. 1996, Skjaerven et al. 2000, Kramer et al. 2002) may be due to improved nutrition and affluence. Additionally, in a number of developed countries, there has been a steady decline in the incidence of cardiovascular 
disease (Tunstall-Pedoe et al. 1999) which has occurred too fast to be a result of genetic change. There is no doubt an important influence of changes in environmental factors affecting adult disease, but there may also be a contribution related to improved fetal and postnatal nutrition. In contrast, the prevalence of type 2 diabetes is increasing in developed countries; however, this is likely to be secondary to the epidemic of obesity in the developed world (Fall 2001).

Evidence from the Nauruan population provides further support for the suggestion that the intergenerational effects of fetal programming on glucose tolerance might be self-limiting. The Nauruans are a small Pacific Island population who suffered nutritional deficiency and drought before and during World War II. With the advent of affluence in the post-war years nutrition improved, and from the 1950s the population suffered an epidemic of obesity and glucose intolerance. Evidence from a survey of the islanders in 1987 suggested that the extremely high incidence of glucose intolerance and type 2 diabetes may be declining (Dowse et al. 1991). Although there has been no change in the prevalence of obesity, and no increase in exercise, there has been a marked decrease in the prevalence of impaired glucose tolerance. The authors speculate that this may be due to a genetic effect, suggesting that the females with impaired glucose tolerance are less fertile and have a smaller number of live births than women with normal glucose tolerance. This change has occurred very rapidly and an alternative explanation could be that improved fetal and infant nutrition consequent on affluence leads to fewer individuals who are at risk of diabetes because of intrauterine programming (Ozanne \& Hales 1998). In contrast, the lack of such an effect in the Pima Indian population (Dabelea et al. 2000b) may be due to differences in the underlying genetic predisposition to diabetes in these different populations.

Thus, there are a number of potential outcomes of fetal programming. Low birth weight babies who do not exhibit catch-up growth are themselves more likely to give birth to low birth weight babies, demonstrating an intergenerational effect on birth weight. In contrast, low birth weight babies who do exhibit catch-up growth, particularly those who become obese, are at increased risk of cardiovascular disease. Women who develop type 2 diabetes or gestational diabetes are likely to give birth to macrosomic infants, themselves at risk of type 2 diabetes later in life. Such consequences may be seen with the rapid urbanisation of populations as described. Finally, populations exposed to a gradual improvement in the environment over a number of generations are more likely to avoid these consequences.

\section{Conclusions}

The association between low birth weight and subsequent disease has been well documented; however, it is also clear that fetal programming effects may not be limited to the first generation. Indeed, intergenerational effects may masquerade as a genetic predisposition to cardiovascular disease in subsequent generations. There is some evidence from human studies that non-genetic effects may be associated with the intergenerational transmission of disease risk. However, any impact of such intergenerational effects will result from the interaction of genes and the preand postnatal environment, and will also occur against a heterogeneous background of genetic susceptibility. Thus, the importance of any effects in different populations will be variable, and it will be difficult to tease out the relative importance of each in any one human population. Nevertheless, there is compelling evidence from animal studies that non-genomic intergenerational effects could operate to produce programming effects across a number of generations.

Intergenerational effects of fetal programming may have major public health implications for developed and developing worlds. Additionally, there may be unforeseen long-term and intergenerational effects of interventions that impact on early human development. Finally, policies aimed at improving the health of one generation, in particular those directed at improving maternal, fetal and infant health and at reducing obesity, may have important benefits for a number of succeeding generations.

\section{Acknowledgements}

A J D and B R W are British Heart Foundation Research Fellows.

\section{References}

Alberman E, Emanuel I, Filakti H \& Evans SJ 1992 The contrasting effects of parental birthweight and gestational age on the birthweight of offspring. Paediatric and Perinatal Epidemiology 6 134-144.

Alcolado JC \& Alcolado R 1991 Importance of maternal history of non-insulin dependent diabetic patients. British Medical Journal 302 1178-1180.

Barker D 1998 In utero programming of chronic disease. Clinical Science 95 115-128.

Barker DJ \& Osmond C 1986 Infant mortality, childhood nutrition, and ischaemic heart disease in England and Wales. Lancet 1 1077-1081.

Barker DJ, Osmond C, Golding J, Kuh D \& Wadsworth ME 1989 Growth in utero, blood pressure in childhood and adult life, and mortality from cardiovascular disease. British Medical Journal 298 564-567.

Barker DJ, Gluckman PD, Godfrey KM, Harding JE, Owens JA \& Robinson JS 1993 Fetal nutrition and cardiovascular disease in adult life. Lancet 341 938-941.

Barker DJ, Shiell AW, Barker ME \& Law CM 2000 Growth in utero and blood pressure levels in the next generation. Journal of Hypertension 18 843-846.

Bavdekar A, Yajnik CS, Fall CH, Bapat S, Pandit AN, Deshpande V, Bhave S, Kellingray SD \& Joglekar C 1999 Insulin resistance syndrome in 8-year-old Indian children: small at birth, big at 8 years, or both? Diabetes 48 2422-2429. 
Benediktsson R, Lindsay RS, Noble J, Seckl JR \& Edwards CR 1993 Glucocorticoid exposure in utero: new model for adult hypertension. Lancet 341 339-341.

Benediktsson R, Noble J, Calder AA, Edwards CR \& Seckl JR 1995 $11 \beta$-Hydroxysteroid dehydrogenase activity in intact dually perfused fresh human placenta predicts birth weight. Journal of Endocrinology 144 (Suppl) 161.

Bjornholt JV, Erikssen G, Liestol K, Jervell J, Thaulow E \& Erikssen J 2000 Type 2 diabetes and maternal family history: an impact beyond slow glucose removal rate and fasting hyperglycemia in low-risk individuals? Results from 22.5 years of follow-up of healthy nondiabetic men. Diabetes Care 23 1255-1259.

Bloom SL, Sheffield JS, McIntire DD \& Leveno KJ 2001 Antenatal dexamethasone and decreased birth weight. Obstetrics and Gynecology 97 485-490.

Boucher BJ 1998 Inadequate vitamin D status: does it contribute to the disorders comprising syndrome ' $\mathrm{X}$ '? British Journal of Nutrition 79 315-327.

Brown MA, Davis GK \& McHugh L 2001 The prevalence and clinical significance of nocturnal hypertension in pregnancy. Journal of Hypertension 19 1437-1444.

Buchbinder A, Sibai BM, Caritis S, Macpherson C, Hauth J, Lindheimer MD, Klebanoff M, Vandorsten P, Landon M, Paul R et al. 2002 Adverse perinatal outcomes are significantly higher in severe gestational hypertension than in mild preeclampsia. American Journal of Obstetrics and Gynecology 186 66-71.

Carr-Hill R, Campbell DM, Hall MH \& Meredith A 1987 Is birth weight determined genetically? British Medical Journal 295 687-689.

Catalano PM, Kirwan JP, Haugel-De Mouzon S \& King J 2003 Gestational diabetes and insulin resistance: role in short- and long-term implications for mother and fetus. Journal of Nutrition 133 (Suppl 2) 1674-1683.

Cawley RH, McKeown T \& Record RG 1954 Parental stature and birth weight. Annals of Human Genetics 6 448-456.

Ceesay SM, Prentice AM, Cole TJ, Foord F, Weaver LT, Poskitt EM \& Whitehead RG 1997 Effects on birth weight and perinatal mortality of maternal dietary supplements in rural Gambia: 5-year randomised control trial. British Medical Journal 315 786-790.

Challis JRG, Sloboda D, Matthews SG, Holloway A, Alfaidy N, Patel FA, Whittle W, Fraser M, Moss TJM \& Newnham J 2001 The fetal placental hypothalamic-pituitary-adrenal (HPA) axis, parturition and post natal health. Molecular and Cellular Endocrinology 185 135-144.

Chike-Obi U, David RJ, Coutinho R \& Wu SY 1996 Birth weight has increased over a generation. American Journal of Epidemiology 144 563-569.

Churchill D, Perry I \& Beevers D 1997 Ambulatory blood pressure in pregnancy and fetal growth. Lancet 349 7-10.

Cleasby M, Kelly PA, Walker BR \& Seckl JR 2003 Programming of rat muscle and fat metabolism by in utero over-exposure to glucocorticoids. Endocrinology 144 999-1007.

Collins JW, Wu SY \& David RJ 2002 Differing intergenerational birth weights among the descendants of US-born and foreign-born Whites and African Americans in Illinois. American Journal of Epidemiology 155 210-216.

Constancia M, Hemberger M, Hughes J, Dean W, Ferguson Smith A, Fundele R, Stewart F, Kelsey G, Fowden A, Sibley C \& Reik W 2002 Placental-specific IGF-II is a major modulator of placental and fetal growth. Nature 417 945-948.

Conti J, Abraham S \& Taylor A 1998 Eating behaviour and pregnancy outcome. Journal of Psychosomatic Research 44 465-477.

Coutinho R, David RJ \& Collins JW Jr 1997 Relation of parental birth weights to infant birth weight among African Americans and whites in Illinois: a transgenerational study. American Journal of Epidemiology 146 804-809.

Cruickshank JK, Mbanya JC, Wilks R, Balkau B, McFarlane-Anderson N \& Forrester T 2001 Sick genes, sick individuals or sick populations with chronic disease? The emergence of diabetes and high blood pressure in African-origin populations. International Journal of Epidemiology 30 111-117.

Dabelea D, Hanson RL, Lindsay RS, Pettitt DJ, Imperatore G, Gabir MM, Roumain J, Bennett PH \& Knowler WC 2000a Intrauterine exposure to diabetes conveys risks for type 2 diabetes and obesity: a study of discordant sibships. Diabetes 49 2208-2211.

Dabelea D, Knowler WC \& Pettitt DJ $2000 \mathrm{~b}$ Effect of diabetes in pregnancy on offspring: follow-up research in the Pima Indians. Journal of Maternal-Fetal Medicine 9 83-88.

Davey Smith G, Hart C, Ferrell C, Upton M, Hole D, Hawthorne V \& Watt G 1997 Birth weight of offspring and mortality in the Renfrew and Paisley study: prospective observational study. British Medical Journal 315 1189-1193.

Davey Smith G, Harding S \& Rosato M 2000a Relation between infants' birth weight and mothers' mortality: prospective observational study. British Medical Journal 320 839-840.

Davey Smith G, Whitley E, Gissler M \& Hemminki E $2000 b$ Birth dimensions of offspring, premature birth, and the mortality of mothers. Lancet 356 2066-2067.

Dean F \& Matthews SG 1999 Maternal dexamethasone treatment in late gestation alters glucocorticoid and mineralocorticoid receptor mRNA in the fetal guinea pig brain. Brain Research 846 253-259.

Dean F, Yu C, Lingas RI \& Matthews SG 2001 Prenatal glucocorticoid modifies hypothalamo-pituitary-adrenal regulation in prepubertal guinea pigs. Neuroendocrinology 73 194-202.

Dean W, Bowden L, Aitchison A, Klose J, Moore T, Meneses JJ, Reik W \& Feil R 1998 Altered imprinted gene methylation and expression in completely ES cell-derived mouse fetuses: association with aberrant phenotypes. Development 125 2273-2282.

Denton KM, Flower RL, Stevenson KM \& Anderson WP 2003 Adult rabbit offspring of mothers with secondary hypertension have increased blood pressure. Hypertension 41 634-639.

Dowse GK, Zimmet PZ, Finch CF \& Collins VR 1991 Decline in incidence of epidemic glucose intolerance in Nauruans: implications for the 'thrifty genotype'. American Journal of Epidemiology 133 1093-1104.

Doyle LW, Ford GW, Davis NM \& Callanan C 2000 Antenatal corticosteroid therapy and blood pressure at 14 years of age in preterm children. Clinical Science 98 137-142.

Dunger DB, Ong KK, Huxtable SJ, Sherriff A, Woods KA, Ahmed ML, Golding J, Pembrey ME, Ring S, Bennett ST et al. 1998 Association of the INS VNTR with size at birth. ALSPAC Study Team. Avon Longitudinal Study of Pregnancy and Childhood. Nature Genetics 19 98-100.

Dunlop SA, Archer MA, Quinlivan JA, Beazley LD \& Newnham JP 1997 Repeated prenatal corticosteroids delay myelination in the ovine central nervous system. Journal of Maternal-Fetal Medicine 6 309-313.

Edwards CR, Benediktsson R, Lindsay RS \& Seckl JR 1993 Dysfunction of placental glucocorticoid barrier: link between fetal environment and adult hypertension? Lancet 341 355-357.

Edwards CR, Benediktsson R, Lindsay RS \& Seckl JR 1996 11-beta-Hydroxysteroid dehydrogenases: key enzymes in determining tissue-specific glucocorticoid effects. Steroids $\mathbf{6 1}$ 263-269.

Egeland GM, Skjaerven R \& Irgens LM 2000 Birth characteristics of women who develop gestational diabetes: population based study. British Medical Journal 321 546-547.

Emanuel I 1986 Maternal health during childhood and later reproductive performance. Annals of the New York Academy of Sciences 477 27-39.

Emanuel I 1997 Invited commentary: an assessment of maternal intergenerational factors in pregnancy outcome. American Journal of Epidemiology 146 820-825. 
Emanuel I, Filakti H, Alberman E \& Evans SJ 1992 Intergenerational studies of human birthweight from the 1958 birth cohort. 1. Evidence for a multigenerational effect. British Journal of Obstetrics and Gynaecology 99 67-74.

Emanuel I, Leisenring W, Williams MA, Kimpo C, Estee S, O’Brien W \& Hale CB 1999 The Washington State Intergenerational Study of Birth Outcomes: methodology and some comparisons of maternal birthweight and infant birthweight and gestation in four ethnic groups. Paediatric and Perinatal Epidemiology 13 352-369.

Eriksson JG, Forsen T, Tuomilehto J, Winter PD, Osmond C \& Barker DJ 1999 Catch-up growth in childhood and death from coronary heart disease: longitudinal study. British Medical Journal 318 $427-431$.

Fall CH 2001 Non-industrialised countries and affluence. British Medical Bulletin 60 33-50.

Fall CH, Yajnik CS, Rao S, Davies AA, Brown N \& Farrant HJW 2003 Micronutrients and fetal growth. Journal of Nutrition $\mathbf{1 3 3}$ (Suppl 2) 1747-1756.

Ferrer RL, Sibai BM, Mulrow CD, Chiquette E, Stevens KR \& Cornell J 2000 Management of mild chronic hypertension during pregnancy: a review. Obstetrics and Gynecology 96 849-860.

Forest MG, David M \& Morel Y 1993 Prenatal diagnosis and treatment of 21-hydroxylase deficiency. Journal of Steroid Biochemistry and Molecular Biology 45 75-82.

Forhead AJ, Li J, Gilmour RS \& Fowden AL 1998 Control of hepatic insulin-like growth factor II gene expression by thyroid hormones in fetal sheep near term. American Journal of Physiology 275 E149-E156.

Forsen T, Eriksson J, Tuomilehto J, Reunanen A, Osmond C \& Barker D 2000 The fetal and childhood growth of persons who develop type 2 diabetes. Annals of Internal Medicine 133 176-182.

Francis D, Diorio J, Liu D \& Meaney MJ 1999 Nongenomic transmission across generations of maternal behavior and stress responses in the rat. Science 286 1155-1158.

French NP, Hagan R, Evans SF, Godfrey M \& Newnham JP 1999 Repeated antenatal corticosteroids: size at birth and subsequent development. American Journal of Obstetrics and Gynecology 180 114-121.

Gillman MW, Rifas-Shiman S, Berkey CS, Field AE \& Colditz GA 2003 Maternal gestational diabetes, birth weight, and adolescent obesity. Pediatrics 111 E221-E226.

Godfrey K \& Robinson S 1998 Maternal nutrition, placental growth and fetal programming. Proceedings of the Nutrition Society $\mathbf{5 7}$ 105-111.

Greenhalgh PM 1997 Diabetes in British South Asians: nature, nurture and culture. Diabetic Medicine 14 10-18.

Groop L, Forsblom C, Lehtovirta M, Tuomi T, Karanko S, Nissen M, Ehrnstrom BO, Forsen B, Isomaa B, Snickars B et al. 1996 Metabolic consequences of a family history of NIDDM (the Botnia study): evidence for sex-specific parental effects. Diabetes $\mathbf{4 5}$ 1585-1593.

Hackman E, Emanuel I, van Belle G \& Daling J 1983 Maternal birth weight and subsequent pregnancy outcome. Journal of the American Medical Association $2502016-2019$.

Hales CN \& Barker DJ 2001 The thrifty phenotype hypothesis. British Medical Bulletin 60 5-20.

Hales CN, Desai M, Ozanne SE \& Crowther NJ 1996 Fishing in the stream of diabetes: from measuring insulin to the control of fetal organogenesis. Biochemical Society Transactions $\mathbf{2 4}$ 341-350.

Hattersley AT \& Tooke JE 1999 The fetal insulin hypothesis: an alternative explanation of the association of low birthweight with diabetes and vascular disease. Lancet 353 1789-1792.

Hattersley AT, Beards F, Ballantyne E, Appleton M, Harvey R \& Ellard S 1998 Mutations in the glucokinase gene of the fetus result in reduced birth weight. Nature Genetics 19 268-270.
Hennessy E \& Alberman E 1998 Intergenerational influences affecting birth outcome. I. Birthweight for gestational age in the children of the 1958 British birth cohort. Paediatric and Perinatal Epidemiology 12 45-60.

Hoet JJ \& Hanson MA 1999 Intrauterine nutrition: its importance during critical periods for cardiovascular and endocrine development. Journal of Physiology 514 617-627.

Huxtable SJ, Saker PJ, Haddad L, Walker M, Frayling TM, Levy JC, Hitman GA, O'Rahilly S, Hattersley AT \& McCarthy MI 2000 Analysis of parent-offspring trios provides evidence for linkage and association between the insulin gene and type 2 diabetes mediated exclusively through paternally transmitted class III variable number tandem repeat alleles. Diabetes 49 126-130.

Hypponen E, Smith GD \& Power C 2003 Parental diabetes and birth weight of offspring: intergenerational cohort study. British Medical Journal 326 19-20.

Ibanez L, Potau N, Enriquez G \& de Zegher F 2000 Reduced uterine and ovarian size in adolescent girls born small for gestational age. Pediatric Research 47 575-577.

Ikegami M, Jobe AH, Newnham J, Polk DH, Willet KE \& Sly P 1997 Repetitive prenatal glucocorticoids improve lung function and decrease growth in preterm lambs. American Journal of Respiratory and Critical Care Medicine 156 178-184.

Innes KE, Byers TE, Marshall JA, Baron A, Orleans M \& Hamman RF 2002 Association of a woman's own birth weight with subsequent risk for gestational diabetes. Journal of the American Medical Association 287 2534-2541.

Johnstone F \& Inglis L 1974 Familial trends in low birth weight. British Medical Journal 3 659-661.

Kaati G, Bygren LO \& Edvinson S 2002 Cardiovascular and diabetes mortality determined by nutrition during parents' and grandparents' slow growth period. European Journal of Human Genetics $\mathbf{1 0}$ 682-688.

Karter AJ, Rowell SE, Ackerson LM, Mitchell BD, Ferrara A, Selby JV \& Newman B 1999 Excess maternal transmission of type 2 diabetes. The Northern California Kaiser Permanente Diabetes Registry. Diabetes Care 22 938-943.

Khosla S, Dean W, Brown D, Reik W \& Feil R 2001 Culture of preimplantation mouse embryos affects fetal development and the expression of imprinted genes. Biology of Reproduction 64 918-926.

Kind KL, Clifton PM, Katsman AI, Tsiounis M, Robinson JS \& Owens JA 1999 Restricted fetal growth and the response to dietary cholesterol in the guinea pig. American Journal of Physiology 277 R1675-R1682.

King H \& Rewers M 1993 Global estimates for prevalence of diabetes mellitus and impaired glucose tolerance in adults. Diabetes Care $\mathbf{1 6}$ 157-177.

Kinra S, Davey Smith G, Okasha M, McCarron P \& McEwen J 2003 Is maternal transmission of coronary heart disease risk stronger than paternal transmission? Heart 89 834-838.

Klebanoff MA, Graubard BI, Kessel SS \& Berendes HW 1984 Low birth weight across generations. Journal of the American Medical Association 252 2423-2427.

Klebanoff MA, Meirik O \& Berendes HW 1989 Second-generation consequences of small-for-dates birth. Pediatrics 84 343-347.

Klebanoff MA, Schulsinger C, Mednick BR \& Secher NJ 1997 Preterm and small-for-gestational-age birth across generations. American Journal of Obstetrics and Gynecology 176 521-526.

Klebanoff MA, Mednick BR, Schulsinger C, Secher NJ \& Shiono PH 1998 Father's effect on infant birth weight. American Journal of Obstetrics and Gynecology 178 1022-1026.

Klebanoff MA, Secher NJ, Mednick BR \& Schulsinger C 1999 Maternal size at birth and the development of hypertension during pregnancy: a test of the Barker hypothesis. Archives of Internal Medicine 159 1607-1612.

Klein BE, Klein R, Moss SE \& Cruickshanks KJ 1996 Parental history of diabetes in a population-based study. Diabetes Care 19 827-830. 
Kramer MS 2002 Balanced protein/energy supplementation in pregnancy (Cochrane Review). In The Cochrane Library, Issue 4, CD 000032.

Kramer MS, Morin I, Yang H, Platt RW, Usher R, McNamara H, Joseph KS \& Wen SW 2002 Why are babies getting bigger? Temporal trends in fetal growth and its determinants. Journal of Pediatrics 141 538-542.

Kuznetsova T, Staessen JA, Olszanecka A, Ryabikov A, Stolarz K, Malyutina S, Fagard R, Kawecka-Jaszcz K \& Nikitin Y 2003 European Project On Genes in Hypertension I Maternal and paternal influences on left ventricular mass of offspring. Hypertension $\mathbf{4 1}$ 69-74.

Langley-Evans SC, Phillips GJ, Benediktsson R, Gardner DS, Edwards CR, Jackson AA \& Seckl JR 1996 Protein intake in pregnancy, placental glucocorticoid metabolism and the programming of hypertension in the rat. Placenta 17 169-172.

Law CM, Shiell AW, Newsome CA, Syddall HE, Shinebourne EA, Fayers PM, Martyn CN \& de Swiet M 2002 Fetal, infant, and childhood growth and adult blood pressure: a longitudinal study from birth to 22 years of age. Circulation 105 1088-1092.

Lawlor DA, Davey Smith G \& Ebrahim S 2002 Birth weight of offspring and insulin resistance in late adulthood: cross sectional survey. British Medical Journal 325 359-362.

Lawlor DA, Davey Smith G \& Ebrahim S 2003a Life course influences on insulin resistance: findings from the British Women's Heart and Health Study. Diabetes Care 26 97-103.

Lawlor DA, Davey Smith G, Whincup P, Wannamethee G, Papacosta O, Dhanjil S, Griffin M, Nicolaides AN \& Ebrahim S $2003 b$ Association between offspring birth weight and atherosclerosis in middle aged men and women: British Regional Heart Study. Journal of Epidemiology and Community Health 57 462-463.

Laychock SG, Vadlamudi S \& Patel MS 1995 Neonatal rat dietary carbohydrate affects pancreatic islet insulin secretion in adults and progeny. American Journal of Physiology 269 E739-E744.

Lesage J, Blondeau B, Grino M, Breant B \& Dupouy JP 2001 Maternal undernutrition during late gestation induces fetal overexposure to glucocorticoids and intrauterine growth retardation, and disturbs the hypothalamo-pituitary-adrenal axis in the newborn rat. Endocrinology 142 1692-1702.

Levitt NS, Lambert EV, Woods D, Hales CN, Andrew R \& Seckl JR 2000 Impaired glucose tolerance and elevated blood pressure in low birth weight, nonobese, young South African adults: early programming of cortisol axis. Journal of Clinical Endocrinology and Metabolism 85 4611-4618.

Li J, Saunders JC, Gilmour RS, Silver M \& Fowden AL 1993 Insulin-like growth factor-II messenger ribonucleic acid expression in fetal tissues of the sheep during late gestation: effects of cortisol. Endocrinology 132 2083-2089.

Li J, Forhead AJ, Dauncey MJ, Gilmour RS \& Fowden AL 2002 Control of growth hormone receptor and insulin-like growth factor-I expression by cortisol in ovine fetal skeletal muscle. Journal of Physiology 541 581-589.

Lin RS, Lee WC, Lee YT, Chou P \& Fu CC 1994 Maternal role in type 2 diabetes mellitus: indirect evidence for a mitochondrial inheritance. International Journal of Epidemiology 23 886-890.

Lindsay RS, Dabelea D, Roumain J, Hanson RL, Bennett PH \& Knowler WC 2000 Type 2 diabetes and low birth weight: the role of paternal inheritance in the association of low birth weight and diabetes. Diabetes 49 445-449.

Lindsay RS, Kobes S, Knowler WC \& Hanson RL 2002a Genome-wide linkage analysis assessing parent-of-origin effects in the inheritance of birth weight. Human Genetics 110 503-509.

Lindsay RS, Prochazka M, Baier LJ, Knowler WC, Bogardus C \& Hanson RL 2002b Currently identified genes affecting insulin resistance are not associated with birth weight in the Pima population. Diabetic Medicine 19 882-884.
Lingas RI \& Matthews SG 2001 A short period of maternal nutrient restriction in late gestation modifies pituitary-adrenal function in adult guinea pig offspring. Neuroendocrinology 73 302-311.

Lingas RI, Dean F \& Matthews SG 1999 Maternal nutrient restriction $(48 \mathrm{~h})$ modifies brain corticosteroid receptor expression and endocrine function in the fetal guinea pig. Brain Research 846 236-242.

Liu D, Diorio J, Tannenbaum B, Caldji C, Francis D, Freedman A, Sharma S, Pearson D, Plotsky PM \& Meaney MJ 1997 Maternal care, hippocampal glucocorticoid receptors, and hypothalamic-pituitary-adrenal responses to stress. Science 277 $1659-1662$.

Liu L, Li A \& Matthews SG 2001 Maternal glucocorticoid treatment programs HPA regulation in adult offspring: sex-specific effects. American Journal of Physiology 280 E729-E739.

Lumey LH 1992 Decreased birthweights in infants after maternal in utero exposure to the Dutch famine of 1944-1945. Paediatric and Perinatal Epidemiology 6 240-253.

Luo J, Reid RE \& Murphy LJ 1990 Dexamethasone increases hepatic insulin-like growth factor binding protein-1 (IGFBP-1) mRNA and serum IGFBP-1 concentrations in the rat. Endocrinology 127 $1456-1462$.

Magnus P, Gjessing HK, Skrondal A \& Skjaerven R 2001 Paternal contribution to birth weight. Journal of Epidemiology and Community Health 55 873-877.

Martin JF, Johnston CS, Han CT \& Benyshek DC 2000 Nutritional origins of insulin resistance: a rat model for diabetes-prone human populations. Journal of Nutrition $130741-744$.

Mathews F, Yudkin P \& Neil A 1999 Influence of maternal nutrition on outcome of pregnancy: prospective cohort study. British Medical Journal 319 339-343.

McCarthy M, Cassell P, Tran T, Mathias L, 't Hart LM, Maassen JA, Snehalatha C, Ramachandran A, Viswanathan M \& Hitman GA 1996 Evaluation of the importance of maternal history of diabetes and of mitochondrial variation in the development of NIDDM. Diabetic Medicine 13 420-428.

McTernan CL, Draper N, Nicholson H, Chalder SM, Driver P, Hewison M, Kilby MD \& Stewart PM 2001 Reduced placental 11 beta-hydroxysteroid dehydrogenase type 2 mRNA levels in human pregnancies complicated by intrauterine growth restriction: an analysis of possible mechanisms. Journal of Clinical Endocrinology and Metabolism 86 4979-4983.

Meaney MJ 2001 Maternal care, gene expression, and the transmission of individual differences in stress reactivity across generations. Annual Review of Neuroscience 24 1161-1192.

Meigs JB, Cupples LA \& Wilson PW 2000 Parental transmission of type 2 diabetes: the Framingham Offspring Study. Diabetes 49 2201-2207.

Mercado AB, Wilson RC, Cheng KC, Wei JQ \& New MI 1995 Prenatal treatment and diagnosis of congenital adrenal hyperplasia owing to steroid 21-hydroxylase deficiency. Journal of Clinical Endocrinology and Metabolism 80 2014-2020.

Merialdi M, Carroli G, Villar J, Abalos E, Gulmezoglu AM, Kulier R \& de Onisz M 2003 Nutritional interventions during pregnancy for the prevention or treatment of impaired fetal growth: an overview of randomized controlled trials. Journal of Nutrition 133 1626S-1631S.

Miell JP, Buchanan CR, Norman MR, Maheshwari HC \& Blum WF 1994 The evolution of changes in immunoreactive serum insulin-like growth factors (IGFs), IGF-binding proteins, circulating growth hormone $(\mathrm{GH})$ and $\mathrm{GH}$-binding protein as a result of short-term dexamethasone treatment. Journal of Endocrinology 142 547-554.

Misra DP 1996 The effect of the pregnancy-induced hypertension on fetal growth: a review of the literature. Paediatric and Perinatal Epidemiology 10 244-263. 
Mitchell BD, Kammerer CM, Reinhart LJ, Stern MP \& MacCluer JW 1995 Is there an excess in maternal transmission of NIDDM? Diabetologia 38 314-317.

Morgan HD, Sutherland HG, Martin DI \& Whitelaw E 1999 Epigenetic inheritance at the agouti locus in the mouse. Nature Genetics 23 314-318.

Mouhieddine OB, Cazals V, Kuto E, Le Bouc Y \& Clement A 1996 Glucocorticoid-induced growth arrest of lung alveolar epithelial cells is associated with increased production of insulin-like growth factor binding protein-2. Endocrinology 137 287-295.

Newnham JP 2001 Is prenatal glucocorticoid administration another origin of adult disease? Clinical and Experimental Pharmacology and Physiology 28 957-961.

Newnham JP, Evans SF, Godfrey M, Huang W, Ikegami M \& Jobe A 1999 Maternal, but not fetal, administration of corticosteroids restricts fetal growth. Journal of Maternal-Fetal Medicine 8 81-87.

Nyirenda MJ, Lindsay RS, Kenyon CJ, Burchell A \& Seckl JR 1998 Glucocorticoid exposure in late gestation permanently programs rat hepatic phosphoenolpyruvate carboxykinase and glucocorticoid receptor expression and causes glucose intolerance in adult offspring. Journal of Clinical Investigation 15 2174-2181.

Ounsted M \& Ounsted C 1968 Rate of intra-uterine growth. Nature $220599-600$

Owen D \& Matthews SG 2003 Glucocorticoids and sex-dependent development of brain glucocorticoid and mineralocorticoid receptors. Endocrinology 144 2775-2784.

Ozanne SE \& Hales CN 1998 Thrifty yes, genetic no. Diabetologia 41 485-487.

Patel MS, Srinivasan M, Aalinkeel R, Song F, Laychock SG, Hill DJ, Petrik J, Coukell S \& Arany E 2001 Maternal influence on pancreatic beta cell development. First World Congress on Fetal Origins of Adult Disease. Mumbai, India. Abstract POS17/17.

Pembrey ME 2002 Time to take epigenetic inheritance seriously. European Journal of Human Genetics 10 669-671.

Petrik J, Reusens B, Arany E, Remacle C, Coelho C, Hoet JJ \& Hill DJ 1999 A low protein diet alters the balance of islet cell replication and apoptosis in the fetal and neonatal rat and is associated with a reduced pancreatic expression of insulin-like growth factor-II. Endocrinology 140 4861-4873.

Pettitt DJ, Nelson RG, Saad MF, Bennett PH \& Knowler WC 1993 Diabetes and obesity in the offspring of Pima Indian women with diabetes during pregnancy. Diabetes Care 16 310-314.

Phillips DI, Barker DJ, Fall CH, Seckl JR, Whorwood CB, Wood PJ \& Walker BR 1998 Elevated plasma cortisol concentrations: a link between low birth weight and the insulin resistance syndrome? Journal of Clinical Endocrinology and Metabolism 83 757-760.

Phillips GJ, Langley-Evans SC, Benediktsson R, Seckl JR, Edwards CRW \& Jackson AA 1994 The role of dietary protein restriction during pregnancy on the activity of placental $11 \beta$-hydroxysteroid dehydrogenase. Proceedings of the Nutrition Society $\mathbf{5 3}$ 170A.

Pinto M \& Shetty P 1995 Influence of exercise-induced maternal stress on fetal outcome in Wistar rats: intergenerational effects. British Journal of Nutrition 73 645-653.

Rakyan VK, Preis J, Morgan HD \& Whitelaw E 2001 The marks, mechanisms and memory of epigenetic states in mammals. Biochemical Journal 356 1-10.

Rakyan VK, Chong S, Champ ME, Cuthbert PC, Morgan HD, Luu KV \& Whitelaw E 2003 Transgenerational inheritance of epigenetic states at the murine Axin $(\mathrm{Fu})$ allele occurs after maternal and paternal transmission. PNAS 100 2538-2543.

Ramakrishnan U, Martorell R, Schroeder DG \& Flores R 1999 Role of intergenerational effects on linear growth. Journal of Nutrition 129 544S-549S

Ravelli AC, van Der Meulen JH, Osmond C, Barker DJ \& Bleker OP 1999 Obesity at the age of $50 \mathrm{y}$ in men and women exposed to famine prenatally. American Journal of Clinical Nutrition $\mathbf{7 0}$ $811-816$
Reik W, Romer I, Barton SC, Surani MA, Howlett SK \& Klose J 1993 Adult phenotype in the mouse can be affected by epigenetic events in the early embryo. Development 119 933-942.

Reik W, Constancia M, Fowden A, Anderson N, Dean W, Ferguson-Smith A, Tycko B \& Sibley C 2003 Regulation of supply and demand for maternal nutrients in mammals by imprinted genes. Journal of Physiology 547 35-44.

Reinisch JM, Simon NG, Karow WG \& Gandelman R 1978 Prenatal exposure to prednisone in humans and animals retards intrauterine growth. Science 202 436-438.

Reynolds RM, Walker BR, Syddall HE, Andrew R, Wood PJ, Whorwood CB \& Phillips DI 2001 Altered control of cortisol secretion in adult men with low birth weight and cardiovascular risk factors. Journal of Clinical Endocrinology and Metabolism $\mathbf{8 6}$ 245-250.

Rich-Edwards JW, Colditz GA, Stampfer MJ, Willett WC, Gillman MW, Hennekens CH, Speizer FE \& Manson JE 1999 Birthweight and the risk for type 2 diabetes mellitus in adult women. Annals of Internal Medicine 130 278-284.

Riley MD, Blizzard CL, McCarty DJ, Senator GB, Dwyer T \& Zimmet P 1997 Parental history of diabetes in an insulin-treated diabetes registry. Diabetic Medicine 14 35-41.

Robinson JS, Moore V, Owens JA \& McMillen IC 2000 Origins of fetal growth restriction. European Journal of Obstetrics and Gynaecology and Reproductive Biology 92 13-19.

Roemer I, Reik W, Dean W \& Klose J 1997 Epigenetic inheritance in the mouse. Current Biology 7 277-280.

Seckl JR 1997 Glucocorticoids, feto-placental 11 beta-hydroxysteroid dehydrogenase type 2 , and the early life origins of adult disease. Steroids 62 89-94.

Seckl JR 1998 Physiologic programming of the fetus. Clinics in Perinatology 25 939-962.

Seghieri G, Anichini R, De Bellis A, Alviggi L, Franconi F \& Breschi MC 2002 Relationship between gestational diabetes mellitus and low maternal birth weight. Diabetes Care 25 1761-1765.

Silverman BL, Rizzo T, Green OC, Cho NH, Winter RJ, Ogata ES, Richards GE \& Metzger BE 1991 Long-term prospective evaluation of offspring of diabetic mothers. Diabetes 40 121-125.

Skjaerven R, Gjessing HK \& Bakketeig LS 2000 Birthweight by gestational age in Norway. Acta Obstetricia et Gynecologica Scandinavica 79 440-449.

Smith GC, Pell JP \& Walsh D 2001 Pregnancy complications and maternal risk of ischaemic heart disease: a retrospective cohort study of 129290 births. Lancet 357 2002-2006.

Smith JT \& Waddell BJ 2000 Increased fetal glucocorticoid exposure delays puberty onset in postnatal life. Endocrinology 141 2422-2428.

Srinivasan M, Aalinkeel R, Song F \& Patel MS 2003 Programming of islet functions in the progeny of hyperinsulinemic/obese rats. Diabetes 52 984-990.

Stein AD \& Lumey LH 2000 The relationship between maternal and offspring birth weights after maternal prenatal famine exposure: the Dutch Famine Birth Cohort Study. Human Biology 72 641-654.

Stein AD, Barnhart HX, Hickey M, Ramakrishnan U, Schroeder DG \& Martorell R 2003 Prospective study of protein-energy supplementation early in life and of growth in the subsequent generation in Guatemala. American Journal of Clinical Nutrition 78 162-167.

Stewart RJ, Preece RF \& Sheppard HG 1975 Twelve generations of marginal protein deficiency. British Journal of Nutrition 33 233-253.

Stewart RJ, Sheppard H, Preece R \& Waterlow JC 1980 The effect of rehabilitation at different stages of development of rats marginally malnourished for ten to twelve generations. British Journal of Nutrition 43 403-412.

Thomas F, Balkau B, Vauzelle-Kervroedan F \& Papoz L 1994 Maternal effect and familial aggregation in NIDDM. The CODIAB Study. CODIAB-INSERM-ZENECA Study Group. Diabetes 43 63-67. 
Tunstall-Pedoe H, Kuulasmaa K, Mahonen M, Tolonen H, Ruokokoski E \& Amouyel P 1999 Contribution of trends in survival and coronary-event rates to changes in coronary heart disease mortality: 10-year results from 37 WHO MONICA project populations. Monitoring trends and determinants in cardiovascular disease. Lancet 353 1547-1557.

Vadlamudi S, Kalhan S \& Patel M 1995 Persistence of metabolic consequences in the progeny of rats fed a $\mathrm{HC}$ formula in their early postnatal life. American Journal of Physiology 269 E731-E738.

Vagero D \& Leon D 1994 Ischaemic heart disease and low birth weight: a test of the fetal-origins hypothesis from the Swedish Twin Registry. Lancet 343 260-263.

Viswanathan M, McCarthy MI, Snehalatha C, Hitman GA \& Ramachandran A 1996 Familial aggregation of type 2 (non-insulin-dependent) diabetes mellitus in south India: absence of excess maternal transmission. Diabetic Medicine 13 232-237.

Walker BR, McConnachie A, Noon JP, Webb DJ \& Watt GC 1998 Contribution of parental blood pressures to association between low birth weight and adult high blood pressure: cross sectional study. British Medical Journal 316 834-837.

Walker BR, Irving RJ, Andrew R \& Belton NR 2002 Contrasting effects of intrauterine growth retardation and premature delivery on adult cortisol secretion and metabolism in man. Clinical Endocrinology 57 351-355.

Walton A \& Hammond J 1938 The maternal effects on growth and conformation in Shire horse-Shetland pony crosses. Proceedings of the Royal Society of London. Series B, Biological Sciences $\mathbf{1 2 5}$ 311-335.

Waterland RA \& Jirtle RL 2003 Transposable elements: targets for early nutritional effects on epigenetic gene regulation. Molecular and Cellular Biology 23 5293-5300.

Watt G, Foy C, Holton D \& Edwards H 1991 Prediction of high blood pressure in young people; the limited usefulness of parental blood pressure data. Journal of Hypertension 9 55-58.
Weaver IC, Szyf M \& Meaney MJ 2002 From maternal care to gene expression: DNA methylation and the maternal programming of stress responses. Endocrine Research 28699.

Welberg LA, Seckl JR \& Holmes MC 2000 Inhibition of 11 beta-hydroxysteroid dehydrogenase, the foeto-placental barrier to maternal glucocorticoids, permanently programs amygdala GR mRNA expression and anxiety-like behaviour in the offspring. European Journal of Neuroscience 12 1047-1054.

Williams MA, Emanuel I, Kimpo C, Leisenring WM \& Hale CB 1999 A population-based cohort study of the relation between maternal birthweight and risk of gestational diabetes mellitus in four racial/ethnic groups. Paediatric and Perinatal Epidemiology 13 452-465.

Woodall SM, Breier BH, Johnston BM \& Gluckman PD 1996 A model of intrauterine growth retardation caused by chronic maternal undernutrition in the rat: effects on the somatotrophic axis and postnatal growth. Journal of Endocrinology 150 231-242.

Yajnik CS, Coyaji KJ, Joglekar CV, Kellingray S \& Fall C 2001 Paternal insulin resistance and fetal growth: problem for the 'fetal insulin' and the 'fetal origins' hypotheses. Diabetologia 44 1197-1198.

Young LE 2001 Imprinting of genes and the Barker hypothesis. Twin Research 4 307-317.

Young LE, Fernandes K, McEvoy TG, Butterwith SC, Gutierrez CG, Carolan C, Broadbent PJ, Robinson JJ, Wilmut I \& Sinclair KD 2001 Epigenetic change in IGF2R is associated with fetal overgrowth after sheep embryo culture. Nature Genetics $\mathbf{2 7}$ 153-154.

Received in final form 12 September 2003

Accepted 18 September 2003

Made available online as an

Accepted Preprint 26 September 2003 